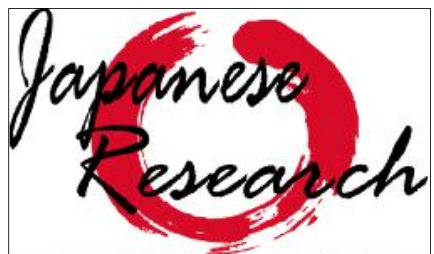

on Linguistics, Literature and Culture
Japanese Research on Linguistics, Literature, and Culture

Vol. 1 No. 2 May 2019, Hal. 167-197

ISSN online: $2655-4836$

http://publikasi.dinus.ac.id/index.php/irllc/article/view/2503/1697

DOI : 10.33633/ir.v1i2.2503

Published by Universitas Dian Nuswantoro, Semarang

\title{
Penggunaan Ungkapan Beri-Terima Bahasa Jepang dalam Novel Shiro no Naka no Hito Karya Hoshi Shin'ichi
}

\author{
Ana Wuri Retnaningrum \\ MAN 1 Pekalongan \\ anawr@gmail.com
}

Article History: Submitted date 01-06-2019; Accepted date 24-09-2019; Published date 25-09-2019

\begin{abstract}
This paper discusses the use of yari-morai phrase (jujuhyougen) found in a novel data source titled Shiro no Naka no Hito. The purpose of this study is to describe the use of expressions of acceptance using Natsuko Tsujimura's theory. The items analyzed in this study are the function, role, and social distance of each argument. From the data analysis, it is found that when analyzed in a syntactic way, each argument functions as a subject and is a direct object or an indirect object. In semantic analysis, from the use of his verb, every argument plays the role of agent and beneficiary. Whereas from the use of passive expressions, each argument acts as a source and a goal. If pragmatic analysis is used, the use of the expressions is influenced by the vertical distance. However, formal situations are more important than existing vertical distances. So that also affects the use of proper expressions.
\end{abstract}

Keywords: yari-morai phrase, jujuhyougen, argument

\begin{abstract}
Abstrak
Tulisan ini membahas penggunaan ungkapan beri-terima (jujuhyougen) yang terdapat dalam sumber data novel berjudul Shiro no Naka no Hito. Tujuan penelitian ini adalah mendeskripsikan penggunaan ungkapan beri-terima dengan menggunakan teori Natsuko Tsujimura. Hal-hal yang dianalisis dalam penelitian ini, terdiri dari fungsi, peran, dan jarak sosial dari tiap-tiap argumen. Dari hasil analisis data, diperoleh hasil bahwa jika dianalisis secara sintaksis, tiap-tiap argumen berfungsi sebagai subjek dan objek langsung atau objek tak langsung. Dalam analisis secara semantik, jika dilihat dari penggunaan kata kerjanya, tiap-tiap argumen berperan sebagai agent dan beneficiary. Sedangkan jika dilihat dari penggunaan ungkapan beri-terima, tiap-tiap argumen berperan sebagai source dan goal. Jika dianalisis secara pragmatik, penggunaan ungkapan beri-terima dipengaruhi oleh adanya jarak vertikal. Namun, situasi formal lebih penting daripada jarak vertikal yang ada. Sehingga hal itu juga mempengaruhi penggunaan ungkapan beriterima yang tepat.
\end{abstract}




\section{Pendahuluan}

Jujuhyougen merupakan ungkapan dalam bahasa Jepang yang digunakan untuk mengungkapkan beri-terima yang mempunyai karakteristik yang khas. Setidaknya terdapat 7 (tujuh) kata kerja yang dapat digunakan untuk mengungkapkan beri-terima yang penggunaannya harus sesuai dengan konteks. Ketujuh ungkapan tersebut adalah sashiageru, ageru, yaru, kudasaru, kureru, itadaku, dan morau. Pemilihan penggunaan ungkapan jujuhyougen yang tepat didasarkan pada situasi, apakah termasuk dalam situasi pemberian ataukah penerimaan, siapakah yang berperan sebagai pemberi dan penerima, dan apa status sosial dari masing-masing pelaku. (Tsujimura, 1996)

Dalam penelitian terdahulu, penulis telah melakukan penelitian yang membahas kesalahan-kesalahan yang dibuat oleh pemelajar bahasa Jepang, khususnya mahasiswa Program Studi Bahasa Jepang Universitas Dian Nuswantoro Semarang mengenai mono no jujuhyougen (ungkapan beri terima benda) dalam bahasa Jepang. Dari penelitian tersebut, diperoleh hasil sebagai berikut.

1) Mahasiswa tidak memahami dengan seksama situasi yang telah dilukiskan.

2) Mahasiswa tidak memahami benar peran dari masing-masing pelaku.

3) Mahasiswa tidak memahami benar status sosial dari para pelaku baik dilihat dari jarak vertikal maupun dilihat dari jarak horisontal.

Dari hasil studi literatur dan analisis data pada penelitian tersebut, dapat disimpulkan bahwa untuk dapat menggunakan mono no jujuhyougen, harus menguasai pemahaman akan situasi, peran, serta status sosial.

Ungkapan beri-terima di dalam bahasa Jepang tidak hanya digunakan untuk tindakan memberi dan menerima sesuatu benda dari seseorang. Namun, lebih lanjut lagi ungkapanungkapan tersebut digunakan untuk menyatakan beri-terima tindakan/perbuatan dari seseorang (Rohadi, 2003). Kalimat benefaktif adalah kalimat yang bersangkutan dengan perbuatan (verba) yang dilakukan untuk orang lain (KBBI, 2002: 132). Dari hal tersebut, dapat 
dikatakan bahwa kalimat yang mengandung ungkapan jujuhyougen termasuk dalam kalimat yang berhubungan dengan tindakan yang dilakukan untuk orang lain..

\subsection{Ungkapan Beri-Terima (Jujuhyougen)}

Jujuhyougen merupakan ungkapan yang digunakan untuk menunjukkan suatu tindakan pemberian dan penerimaan baik benda maupun tindakan/perbuatan. Ungkapan yang digunakan yaitu ageru, sashiageru, yaru, morau, itadaku, kureru, dan kudasaru. Selain disebut jujuhyougen, ungkapan ini juga disebut dengan jukyuu hyougen, yarimorai hyougen, serta agemorai hyougen (Takamizawa Hajime, dkk, 2004).

Pada penelitian ini, teori yang digunakan dalam menganalisis data adalah teori Natsuko Tsujimura. Tsujimura mengungkapkan bahwa dalam bahasa Jepang, ada beberapa ungkapan yang dapat digunakan untuk menunjukkan adanya situasi pemberian dan penerimaan. Adapun penentuan situasi, peran, serta status sosial dari setiap pelaku ditentukan dari sudut pandang saya sebagai pembicara.

Situasi pemberian dibagi menjadi dua situasi yang berbeda. Dalam situasi pertama, pembicara atau uchimono (anggota pembicara) bertindak sebagai pemberi. Oleh Tsujimura digambarkan sebagai "saya, atau uchimono, memberi sesuatu kepada seseorang", ungkapan yang digunakan adalah sashiageru, ageru, dan yaru. Jika kedudukan penerima lebih tinggi daripada pembicara/pemberi mengenai usia, maupun status sosial, maka ungkapan yang dapat digunakan yaitu sashiageru. Jika kedudukan penerima setingkat atau sama dengan pemberi, atau penerima lebih rendah dari pemberi, maka digunakan ungkapan ageru atau yaru, tetapi lebih tepat menggunakan ungkapan ageru, karena ungkapan ageru dianggap lebih sopan dibandingkan ungkapan yaru. Kaum wanita lebih sering menggunakan ungkapan ageru daripada yaru. Dijelaskan pula bahwa benda-benda yang tidak dapat bergerak sendiri, termasuk dalam kedudukan lebih rendah daripada pembicara.

Situasi kedua dalam situasi pemberian yaitu pembicara bertindak sebagai penerima. Tsujimura merumuskan sebagai "seseorang memberi saya atau uchimono sesuatu". Ungkapan yang paling tepat digunakan yaitu kudasaru dan kureru. Kudasaru digunakan jika status sosial pemberi lebih tinggi dari pembicara/penerima, sedangkan jika status sosial pemberi setingkat atau lebih rendah dari pembicara/penerima, digunakan ungkapan kureru. 
Untuk situasi penerimaan, Tsujimura menggambarkan situasi ini sebagai "saya, atau uchimono menerima sesuatu dari seseorang". Ungkapan yang paling tepat digunakan untuk situasi ini yaitu itadaku dan morau. Sangat tidak sopan bagi orang Jepang untuk mengatakan "seseorang menerima sesuatu dari saya". Jadi, penggunaan ungkapan itadaku dan morau pada kalimat ini tidak tepat. Itadaku merupakan ungkapan yang digunakan jika pemberi status sosialnya lebih tinggi daripada pembicara/penerima, sedangkan ungkapan morau dapat digunakan jika pemberi status sosialnya setingkat atau lebih rendah dari pembicara/penerima.

Dalam ungkapan pemberian dan penerimaan tindakan/perbuatan, ketentuan penggunaannya hampir sama seperti dalam pemberian dan penerimaan benda. Perbedaannya ungkapan beri terima tersebut digabung dengan kata kerja bentuk -te, dengan cara meletakkan ungkapan beri terima tersebut di bagian akhir. Perhatikan contoh-contoh berikut!

Watashi ga sensei ni zyuusyo wo kaite-sashiageta.

I teacher address write-gave

I wrote the address for my teacher (Tsujimura, 1996; hal. 341)

Musume ni hon wo yonde-yatta.

Daughter book read-gave

I read a book for my daughter (Tsujimura, 1996; hal. 342)

Dedi Sutedi mengungkapkan dalam bukunya yang berjudul Dasar-dasar Linguistik Bahasa Jepang, bahwa kalimat berdasarkan pada strukturnya secara garis besar terdiri dari dua macam, yaitu yang tidak memiliki unsur predikat dan yang memiliki unsur predikat.

Dalam bukunya yang berjudul Nihongo e no Shoutai yang disusun oleh Tim The Japan Fondations, dijelaskan secara singkat mengenai kalimat berpredikat kata kerja. Dalam sebuah kalimat, subjek berada di awal kalimat. Subjek ditandai dengan partikel ga dan tema/topik ditandai dengan partikel wa. Setelah subjek, ada kata benda yang ditandai dengan partikel wo. Kata benda tersebut menduduki fungsi sebagai objek kalimat. Secara singkat, dapat dilihat dari bagan di bawah ini.

Tabel 2.1 Struktur Kalimat dengan 1 Objek

$$
\mathrm{N}(1) \quad g a \quad \mathrm{~N}(2) \text { wo } \mathrm{V}
$$


Ket: $N(1)$ : Subjek (S)

$N(2)$ : Objek (O)

$\mathrm{V}$ : Predikat $(\mathrm{P})$

Contoh:

$\begin{array}{ccc}\text { Tanaka sensei wa } & \text { terebi wo } & \frac{\text { mimasen }}{\text { Guru Tanaka }} \\ \text { televisi } & \text { tidak melihat }\end{array}$

Selain struktur kalimat seperti di atas, ada juga kalimat yang memiliki 2 objek. Artinya dalam suatu kalimat terdapat 2 argumen lain selain subjek kalimat yang memiliki fungsi yang berbeda. Fungsi tersebut selanjutnya disebut sebagai objek langsung (OL) dan objek tak langsung (OTL). Hal ini dapat dilihat dalam contoh kalimat sebagai berikut.

$\begin{array}{cccc}\text { Contoh: } \frac{\text { Taro }}{\text { Taro }} & \frac{\text { Hanako }}{\text { Hanako }} & \frac{\text { hana wo }}{\text { bunga }} & \frac{\text { okutta }}{\text { mengirim }} \\ \text { S } & \text { OTL } & \text { OL } & \text { P }\end{array}$

Dalam kalimat tersebut, selain Taro yang berfungsi sebagai subjek dalam kalimat, ada argumen lain yang memiliki fungsi yang lain yang muncul dalam kalimat tersebut. Argumen lain tersebut yaitu Hanako ni dan hana wo. Hana menduduki fungsi sebagai objek langsung (OL) dan Hanako menduduki fungsi sebagai objek tak langsung (OTL). Dari uraian kalimat tersebut, dapat digambarkan ke dalam bagan berikut ini.

Tabel 2.2 Struktur Kalimat Dengan 2 Objek

\begin{tabular}{|llllll|}
\hline$N(1)$ & $g a$ & $N(2)$ & ni & N (3)wo & V \\
\hline
\end{tabular}

Ket: $\quad N(1)$ : Subjek (S)

N (2): Objek Tak Langsung (OTL)

$\mathrm{N}(3)$ : Objek Langsung (OL)

$\mathrm{V}$ : Predikat $(\mathrm{P})$

\subsection{Thematic Roles}

Teori dari Andrews (1985) dan Radford (1988) dalam John I. Saeed mengungkapkan tentang Thematic Roles. Thematic Roles digunakan untuk mencari makna dari penggunaan ungkapan jujuhyougen yang digunakan dalam sebuah kalimat dengan cara menganalisis peran 
dari masing-masing argumen dalam kalimat. Dari para peneliti tersebut, diperoleh unsur-unsur yang terdapat dalam thematic roles seperti berikut ini.

AGENT : Pihak yang melakukan aksi/tindakan.

Contoh $\quad$ : Taro ga Hanako ni hana wo ageta

Taro Hanako bunga member

Agent

(Tsujimura, 1996: 310)

PATIENT : Pihak yang mengalami akibat dari beberapa aksi/tindakan.

Contoh : : Isu ga taoreta

Kursi roboh

Patient

(Tsujimura, 1996: 320)

THEME: Pihak yang bergerak dengan aksi/tindakan yang dilakukan.

Contoh : : Taro ga Hanako ni hana wo ageta

Taro Hanako bunga memberi

Theme $\quad$.(Tsujimura, 1996: 310)

EXPERIENCER: Pihak yang secara tidak sengaja mendapatkan efek dari keadaan yang digambarkan oleh predikat yang tidak dapat dikendalikan.

Contoh $\quad$ : Mado ga aiteiru

Jendela terbuka

Exp.

(Tsujimura, 1996:321)

BENEFICIARY: Pihak yang mendapatkan keuntungan dari tindakan yang dilakukan.

Contoh : : Taro ga Hanako ni hana wo ageta

Taro Hanako bunga memberi

Beneficiary

(Tsujimura, 1996: 310)

INSTRUMENT: Alat yang digunakan untuk melakukan aksi/tindakan.

Contoh : Doa ga kono kagi de futatsu aita

Pintu kunci ini dua buah terbuka

Instrument (Tsujimura, 1996: 271)

172 | P a g e 
LOCATION : :Tempat dimana aksi/tindakan itu dilakukan.

Contoh : : Akachan wa nikai de neteiru

Bayi lantai 2 sedang tidur

Location (Tsujimura, 1996: 322)

GOAL : : Tujuan atau kemana tindakan itu dilakukan.

Contoh : : Ziiro ga hon wo Toukyou kara Oosaka made okutta

Ziiro buku Toukyou Oosaka mengirim

Goal (Tsujimura,1996: 311)

SOURCE : Sumber darimana asal tindakan tersebut dilakukan.

Contoh : : Ziiro ga hon wo Toukyou kara Oosaka made okutta

Ziiro buku $\begin{gathered}\text { Toukyou Oosaka } \\ \text { Source }\end{gathered}$
(Tsujimura,1996: 311)

\subsection{Jarak Sosial Dalam Masyarakat Jepang}

Ide Sachiko (1982) mengungkapkan teori tentang kesopanan yang dimaknai sebagai

'jarak'. Kutipan teori tersebut adalah sebagai berikut.

Kesopanan dimaknai sebagai distance 'jarak' yang dirasakan oleh peserta tutur. Fungsi jarak disini dipahami sebagai konsep mendasar untuk mengontrol perilaku manusia dalam kesopanan. Jarak peserta tutur dilatarbelakangi oleh (1) jarak sosial berdasarkan kelas sosial, status, usia, dan kekuasaan (power), (2) formalitas, yang berdasarkan pada kurangnya pengetahuan peserta tutur, formalitas peristiwa atau topik, (3) jarak psikologis yang misalnya bergantung pada rasa hormat, avoidance 'penjauhan', kedekatan, dan solidaritas (Ide, 1982 dalam Saifudin, 2005 dalam Kurniawati, 2008)

Jika diperhatikan dari apa yang dikemukakan oleh Sachiko mengenai konsep jarak, jarak yang pertama berhubungan dengan jarak vertikal antarpeserta tutur, lalu jarak yang kedua berkaitan dengan situasi tutur, dan jarak yang ketiga berhubungan dengan jarak horisontal (solidaritas). Jarak tersebut berpengaruh terhadap ikatan dalam hubungan antarmanusia seperti yang dijelaskan oleh Nakane berikut ini. 
Tipe pokok hubungan antarmanusia dapat dibagi-bagi menurut cara mengatur berbagai ikatan, menjadi dua kategori: vertikal dan horisontal. Hubungan anak dan orang tua adalah vertikal, hubungan antara saudara kandung adalah horisontal, hubungan atasan dan bawahan adalah vertikal, sedang hubungan antar rekan sejawat adalah horisontal. (Nakane, 1970 dalam Kurniawati, 2008)

\subsection{Metode Penelitian}

Penelitian ini menggunakan metode analisis data kualitatif. Setelah data terkumpul, kegiatan selanjutnya yaitu menganalisis data. Urutan penganalisisan datanya mengacu pada langkah-langkah sebagai berikut.

Identifikasi dan klasifikasi kalimat jujuhyougen. Dalam tahap ini, semua data yang berupa kalimat tuturan yang mengandung -tejujuhyougen yang terdapat dalam novel dikelompokkan apakah termasuk dalam ungkapan -tesashiageru, -teageru, -teyaru, -tekudasaru, -tekureru, -teitadaku, ataukah -temorau. Sehingga dapat diketahui berapa jumlah setiap ungkapan -tejujuhyougen. Tahap ini merujuk pada teori yang digunakan yaitu Natsuko Tsujimura.

Dalam analisis data, data-data yang dikutip secara langsung dari novel, merupakan struktur kalimat secara lahir yang dituturkan oleh penutur. Dalam menganalisis kalimat, baik fungsi sintaksis maupun peran semantik dari setiap argumen, perlu dimunculkan semua argumen yang ada dalam kalimat. Oleh karena itu, sebelum menganalisis data, ditampilkan juga struktur kalimat secara batin dari penutur. Setelah diketahui struktur batinnya, kemudian dianalisis tentang hal-hal sebagai berikut.

1) Fungsi sintaksis dari setiap argumen, apakah sebagai subjek, predikat (verba), ataukah objek langsung atau tak langsung.

2) Peran semantik dari masing-masing argumen, apakah sebagai Agent, Patient, Theme, Experiencer, Beneficiary, Instrument, Location, Goal, atau Source. Penentuan ini mengacu pada teori John I. Saeed.

3) Analisis penggunaan ungkapan jujuhyougen ditinjau dari jarak sosial yang ada antarpeserta tutur. Penentuan ini mengacu pada teori Ide Sachiko dan Natsuko Tsujimura. 


\section{Hasil dan Pembahasan}

\section{1. -teyaru}

Setelah dilakukan pencarian data, ditemukan 1 kalimat tuturan yang mengandung teyaru di halaman 86 paragraf 3. Kalimatnya berbunyi,

1. (Dewa, mimawatte hagemashite yarou)

(Kalau begitu, ayo kita semangati para pasukan)

Data tersebut merupakan data yang diambil dari tuturan yang diucapkan oleh Hideyori dalam percakapannya dengan Harunaga. Hideyori merupakan seorang anak kaisar bernama Taikou. Sedangkan Harunaga merupakan putra sulung dari seorang kepala menteri keuangan di kerajaannya.

Kedua tokoh ini sedang membicarakan persiapan pasukan yang akan turut serta dalam peperangan melawan Tokugawa. Harunaga sangat yakin akan memenangkan peperangan itu meskipun jumlah pasukan mereka lebih sedikit dibandingkan dengan jumlah pasukan dari pihak Tokugawa. Mendengar keyakinan Harunaga tersebut, Hideyori pun ikut bersemangat, kemudian mengucapkan kalimat dalam data tersebut.

Kalimat tersebut merupakan struktur kalimat secara lahir yang dituturkan oleh Hideyori kepada Harunaga. Aktivitas pemberian semangat tersebut bukan ditujukan kepada Harunaga, namun kepada para pasukan. Jika dituliskan struktur kalimat secara batinnya adalah sebagai berikut.

(Dewa, $\quad$ watashitachi wa gunzei ni mimawatte hagemashite yarou )

Kalau begitu, kita para pasukan berkeliling menyemangati memberi

(Kalau begitu, ayo kita semangati para pasukan)

Dari kalimat yang bergaris bawah di atas, maka dapat dianalisis mengenai fungsi dari setiap argumen sebagai berikut.

$\begin{array}{ccc}\frac{\text { watashitahi wa }}{\text { kita }} & \frac{\text { gunzei ni }}{\text { pasukan }} & \frac{\text { mimawatte hagemashite yarou }}{\text { berkeliling menyemangati memberi }} \\ \text { S } & \text { OL } & \text { P }\end{array}$


Dari analisis tersebut, dapat diketahui bahwa subjek (S) dalam kalimat itu adalah watashitachi. Yang dimaksud watashitachi dalam hal ini yaitu Hideyori dan Harunaga. Gunzei berfungsi sebagai objek langsung $(\mathrm{OL})$ yang dikenai tindakan yang dilakukan oleh Hideyori.

Dalam menganalisis peran setiap argumen yang ada dalam kalimat yang mengandung jujuhyougen yang bermakna tindakan, dapat dilakukan secara 2 tahap yakni ditinjau dari verba yang digunakan dan dari ungkapan jujuhyougen yang digunakan.

Tahap pertama yakni menganalisis peran argumen ditinjau dari verba yang digunakan. Verba mimawattehagemashite yang berasal dari verba mimawattehagemasu yang bermakna berkeliling menyemangati, merupakan verba yang memerlukan adanya pelaku yang berperan sebagai pemberi tindakan dan penerima tindakan tersebut. Sehingga, jika dilihat dari verba yang digunakan, dapat dianalisis argumennya sebagai berikut.

\begin{tabular}{|c|c|c|}
\hline Watashitahiwa & gunzeini & mimawatte hagemashite \\
\hline & $\begin{array}{l}\text { pasukan } \\
\text { Beneficiary }\end{array}$ & $\begin{array}{c}\text { berkeliling menyem } \\
\text { Verba -te }\end{array}$ \\
\hline
\end{tabular}

Dari analisis tersebut, dapat diketahui bahwa pihak yang berperan sebagai agent (pihak yang melakukan aksi/tindakan) adalah watashitachi. Sedangkan gunzei berperan sebagai beneficiary (pihak yang dikenai/menerima tindakan/kebaikan).

Dilihat dari ungkapan jujuhyougen yang digunakan yakni yaru, yang berarti memberi, dapat diketahui bahwa verba tersebut memerlukan adanya pihak yang dituju (goal) dan pihak asal aksi/tindakan dilakukan (source). Sehingga jika ditinjau dari ungkapan jujuhyougen yang digunakan, maka analisis mengenai perannya adalah sebagai berikut.

$\begin{array}{cccc}\text { Watashitahiwa } & \frac{\text { gunzei ni }}{\text { pasukan }} & \begin{array}{l}\text { mimawatte hagemashite } \\ \text { berkeliling menyemangati }\end{array} & \begin{array}{c}\text { yarou } \\ \text { memberi }\end{array} \\ \text { Source } & \text { Goal } & & \text { Verba-juju }\end{array}$

Dari analisis tersebut dapat diketahui bahwa yang berperan sebagai pihak asal yang melakukan aksi/tindakan (source) adalah watashitachi, dan pihak yang dituju (goal) adalah gunzei.

Ditinjau dari segi penggunaan ungkapan yaru yang digunakan oleh Hideyori, hal ini dilandasi oleh adanya jarak peserta tutur seperti yang diungkapkan oleh Sachiko bahwa fungsi 
jarak disini dipahami sebagai konsep mendasar untuk mengontrol perilaku manusia dalam kesopanan. Jarak sosial yang ada dalam kalimat tuturan tersebut dilatarbelakangi oleh adanya jarak vertikal yakni kekuasaan (power). Seperti yang telah diketahui bahwa Hideyori yang merupakan seorang kaisar memiliki kekuasaan yang lebih dibandingkan para pasukannya. Dari hal tersebut dapat disimpulkan bahwa Hideyori memiliki status sosial yang lebih tinggi daripada para pasukannya. Sehingga hal ini sesuai dengan yang diungkapkan oleh Tsujimura bahwa yaru dapat digunakan jika status sosial penerima lebih rendah daripada pemberi. Dalam hal ini, penerimanya yaitu para pasukan, dan pemberinya yaitu Hideyori.

\section{2. -tesashiageru}

Dalam novel tersebut, ditemukan sebanyak 2 kalimat yang mengandung -tesashiageru sebagai berikut.

1. Halaman 77 paragraf 3

(Sakihodonokibou wo kanaete sashiagetakunarimashita)

Keinginan tadi memenuhi menjadi ingin memberikan

(... Saya jadi ingin memenuhi keinginan Yang Mulia tadi......)

2. Halaman 94 paragraf 4

(Miyohimesama dakedeshitara, nantoka shitesashiagemashou...)

Puteri Miyo kalau hanya suatu cara melakukan

(Kalau hanya Puteri Miyo, ayo kita lakukan satu cara untuknya entah bagaimana caranya itu. ...)

Data 1 merupakan kalimat yang diucapkan oleh Ryoui kepada Hideyori. Ryoui adalah seorang pedagang besar berumur kira-kira 60 tahun, yang merupakan rekan ayahnya dulu.

Ryoui bercerita banyak tentang berbagai kehidupan di negeri asing. Cerita tersebut sangat menarik hati Hideyori sehingga membuatnya ingin sekali pergi ke negeri yang diceritakan tersebut dengan mengarungi samudera. Mendengar hal tersebut, Ryoui ingin mewujudkan keinginan Hideyori itu dengan mengatakan kalimat dalam data tersebut.

Kalimat tersebut merupakan struktur kalimat secara lahir yang dituturkan oleh Ryoui kepada Hideyori. Aktivitas keinginan untuk memenuhi harapan/keinginan dilakukan oleh Ryoui kepada Hideyori. Jika dituliskan struktur kalimat secara batinnya adalah sebagai berikut.

Watashi wa anata ni sakihodo no kibou wo kanaete sashiagetakunarimashita

Saya jadi ingin memenuhi keinginan Yang Mulia tadi 
Dari kalimat tersebut, maka dapat dianalisis mengenai fungsi dari setiap argumen sebagai berikut.

Watashi wa anata ni sakihodo no kibou wo kanaete sashiagetakunarimashita

$\begin{array}{ccccc}\text { Saya } & \text { Anda } & \text { keinginan tadi } & \text { memenuhi menjadi ingin memberi } \\ \mathrm{S} & \mathrm{OTL} & \mathrm{OL} & \mathrm{P}\end{array}$

Dari analisis tersebut, dapat diketahui bahwa subjek dalam kalimat itu adalah watashi. Sakihodo no kibou berfungsi sebagai objek langsung yang dikenai tindakan yang dilakukan oleh Ryoui. Sedangkan anata berfungsi sebagai objek tak langsung yang dikenai tindakan oleh watashi. anata yang dimaksud di sini adalah Hideyori.

Pada tahap pertama dalam menganalisis peran dari setiap argumen, jika ditinjau dari verba yang digunakan, verba kanaete yang berasal dari verba kanaeru yang bermakna memenuhi, memerlukan adanya pihak yang memenuhi sesuatu dan pihak yang menerima hasil pemenuhan tersebut. Sehingga analisis peran dari masing-masing argumen seperti yang diungkapkan oleh Saeed adalah sebagai berikut.

Watashi wa anata ni sakihodo no kibou wo kanaete sashiagetakunarimashita

$\begin{array}{lll}\text { Saya Anda } & \text { keinginan tadi memenuhi menjadi ingin memberi } \\ \text { Agent Beneficiary } & \text { Theme } & \text { Verba -te }\end{array}$

Dari analisis tersebut, dapat diketahui bahwa pihak yang berperan sebagai agent (pihak yang melakukan aksi/tindakan) adalah watashi. Sedangkan anata berperan sebagai beneficiary (pihak yang dikenai/menerima tindakan/kebaikan). sedangkan sesuatu yang menjadi objek pergerakan tindakannya (theme) adalah sakihodo no kibou.

Dilihat dari ungkapan jujuhyougen yang digunakan yakni sashiageru, yang berarti memberi, dapat diketahui bahwa verba tersebut memerlukan adanya pihak yang dituju (goal) dan pihak asal yang melakukan aksi/tindakan (source). Sehingga jika ditinjau dari ungkapan jujuhyougen yang digunakan, maka analisis mengenai perannya adalah sebagai berikut.

\begin{tabular}{|c|c|c|c|}
\hline $\mathrm{Nat}$ & & akihoc & sashiagetakunarim \\
\hline & Anda & memenuhi & moni \\
\hline Source & Goal & Theme & Verba-juju \\
\hline
\end{tabular}


Dari analisis tersebut dapat diketahui bahwa yang berperan sebagai pihak asal yang melakukan aksi/tindakan (source) adalah watashi, dan pihak yang dituju (goal) adalah anata.

Ditinjau dari penggunaan ungkapan sashiageru yang digunakan oleh Ryoui, hal ini dilandasi oleh adanya jarak peserta tutur seperti yang diungkapkan oleh Sachiko bahwa fungsi jarak dipahami sebagai konsep mendasar untuk mengontrol perilaku manusia dalam kesopanan. Jarak sosial yang ada dalam kalimat tuturan di atas dilatarbelakangi oleh adanya jarak sosial berdasarkan kelas sosial (jarak vertikal). Seperti yang telah diketahui bahwa Ryoui yang hanya seorang pedagang status sosialnya lebih rendah daripada Hideyori yang seorang kaisar. Dari hal tersebut dapat disimpulkan bahwa hal ini sesuai dengan yang diungkapkan oleh Tsujimura bahwa sashiageru dapat digunakan jika status sosial penerima lebih tinggi daripada pemberi. Dalam hal ini, penerimanya adalah Hideyori dan pemberinya adalah Ryoui.

Sedangkan dalam data 2, data tersebut merupakan kutipan kalimat tuturan yang diucapkan oleh Yuuraku kepada Hideyori. Yuuraku adalah seorang laki-laki berumur kira-kira 65 tahun yang juga merupakan anak laki-laki dari Nobunaga. Nobunaga adalah paman dari Yodogimi (ibu Hideyori) yang juga sebagai pendamping Taikou.

Kedua tokoh ini sedang membicarakan kemenangan yang telah diraih Hideyori melawan Tokugawa. Di sela-sela pembicaraan itu, Hideyori menginginkan agar Yuuraku membantunya untuk membebaskan Puteri Miyo (istri Hideyori) yang disandera oleh Takadaiin. Mendengar hal itu, kemudian Yuuraku mengatakan kalimat tersebut.

Kalimat tersebut merupakan struktur kalimat secara lahir yang dituturkan oleh Yuuraku kepada Hideyori. Aktivitas melakukan sesuatu tersebut dilakukan oleh Yuuraku kepada Hideyori. Jika dituliskan struktur kalimat secara batinnya adalah sebagai berikut.

(Miyohime dake deshitara, watashitachi wa Miyohimesama ni nantoka shitesashiagemashou) itu. ...)

(Kalau hanya Puteri Miyo, ayo kita lakukan satu cara untuknya entah bagaimana caranya

Kalimat yang bergaris bawah tersebut, dapat dianalisis fungsi dari setiap argumennya sebagai berikut.

Watashitachi wa Miyohimesama ni

nantoka shite sashiagemashou 
Kita

$\mathrm{S}$
Puteri Miyo

$\mathrm{OL}$ satu cara melakukan memberi

$P$

Dari analisis kalimat di atas, dapat diketahui bahwa subjek dalam kalimat itu adalah watashitachi. Miyohimesama berfungsi sebagai objek langsung yang dikenai tindakan yang dilakukan oleh Yuuraku.

Dalam analisis peran setiap argumen, jika ditinjau dari verba yang digunakan, verba shite yang berasal dari verba suru yang bermakna melakukan, memerlukan adanya pihak yang melakukan sesuatu dan pihak yang menerima perlakuan tersebut. Sehingga analisis peran dari tiap-tiap argumen seperti yang diungkapkan oleh Saeed adalah sebagai berikut.

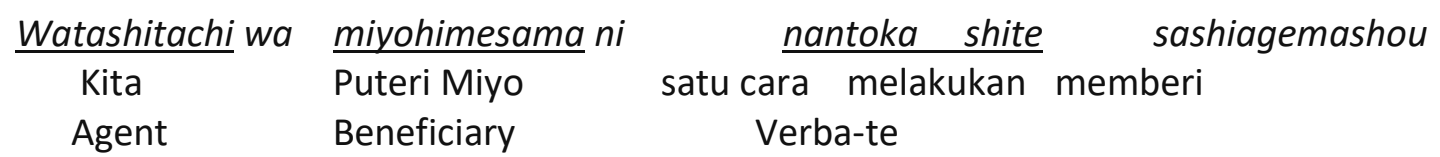

Dari analisis tersebut, dapat diketahui bahwa pihak yang berperan sebagai agent (pihak yang melakukan aksi/tindakan) adalah watashi. Sedangkan Miyohimesama berperan sebagai beneficiary (pihak yang dikenai/menerima tindakan/kebaikan).

Sedangkan jika ditinjau dari penggunaan ungkapan jujuhyougen yang digunakan, maka analisis perannya adalah sebagai berikut.

\begin{tabular}{|c|c|c|c|c|}
\hline Watashitachi wa & miyohimesama ni & & antoka & sashiagemashou \\
\hline & Puteri Miyo & satu cara & melakukan & memberi \\
\hline Source & Goal & & & Verba-juju \\
\hline
\end{tabular}

Dari analisis di atas, dapat diketahui bahwa yang berperan sebagai pihak asal yang melakukan aksi/tindakan (source) adalah watashi, dan pihak yang dituju (goal) adalah Miyohimesama.

Ditinjau dari penggunaan ungkapan sashiageru yang digunakan oleh Yuuraku, hal ini dilandasi oleh adanya jarak peserta tutur seperti yang diungkapkan oleh Sachiko bahwa fungsi jarak dipahami sebagai konsep mendasar untuk mengontrol perilaku manusia dalam kesopanan. Jarak sosial yang ada dalam kalimat tuturan di atas dilatarbelakangi oleh adanya jarak sosial berdasarkan jarak vertikal yakni kekuasaan (power). Seperti yang diketahui bahwa Miyohimesama adalah istri dari Hideyori. Sehingga Miyohimesama memiliki status sosial yang lebih tinggi daripada Yuuraku. Dari hal tersebut dapat disimpulkan bahwa hal ini sesuai dengan 
yang diungkapkan oleh Tsujimura bahwa sashiageru dapat digunakan jika status sosial penerima lebih tinggi daripada pemberi. Dalam hal ini, penerimanya adalah Miyohimesama dan pemberinya adalah Yuuraku.

\section{3. -tekureru}

Dalam novel tersebut, ditemukan sebanyak 2 kalimat yang mengandung -tekureru sebagai berikut.

1. Halaman 51 paragraf 7

(Sou itte kureru to

ureshii )

Berkata demikian

berbesar hati

(Aku merasa lega kamu berkata demikian)

2. Halaman 91 paragraf 5

(Senjitsuno tatakaidewa, taisou

Tempo hari di peperangan, banyak sepertinya melakukan

(Di peperangan yang terjadi beberapa waktu yang lalu, sepertinya banyak yang telah Anda lakukan untuk saya ya)

Data 1 merupakan data pertama dalam pola -tekureru. Data tersebut merupakan kutipan kalimat yang dituturkan oleh Hideyori kepada Shigenari. Shigenari adalah teman sepermainan Hideyori yang juga merupakan anak dari seorang kepala kementerian.

Suatu hari, di tengah keasyikan mereka bermain, Hideyori megatakan ingin sekali dapat menekuni ilmu beladiri seperti yang dilakukan oleh Shigenari, agar jika suatu saat harus berhadapan dengan musuh, ia dapat melawannya, meskipun hanya dengan menodongkan anak panah untuk menakut-nakuti. Namun, hal ini dibantah oleh Shigenari. Menurut Shigenari, bahwa menekuni ilmu beladiri bukanlah untuk hal seperti itu, baginya jika berhadapan dengan musuh, ia akan mempertaruhkan seluruh jiwa dan raganya. Mendengar hal itu Hideyori berkomentar dengan mengatakan kalimat seperti di dalam data.

Kalimat tersebut merupakan struktur kalimat secara lahir yang dituturkan oleh Hideyori (seorang kaisar) kepada Shigenari (seorang anak kepala kementrian, yang juga teman sepermainan Hideyori). Aktivitas perkataan yang membuat lega tersebut ditujukan kepada Hideyori oleh Shigenari. Sehingga jika dituliskan secara lengkap tentang struktur kalimat batinnya, kalimatnya adalah sebagai berikut.

Anata wa watashi ni sou itte kureru to ureshii 
Aku merasa lega kamu berkata demikian kepadaku

Dari kalimat di atas, anata yang dimaksud adalah Shigenari. Analisis mengenai fungsi dari setiap argumen dalam kalimat tersebut adalah sebagai berikut.

$\begin{array}{cccc}\frac{\text { Anata }}{\text { Kamu }} & \frac{\text { watashi }}{\text { sami }} & \text { sou itte kureru to } & \text { ureshii } \\ \text { S } & \text { OL } & \text { berkata demikian } & \text { berbesar hati } \\ & \text { P } & \text { P } & \end{array}$

Dari kalimat tersebut, dapat diketahui bahwa subjeknya adalah anata, dan objek langsungnya adalah watashi.

Dalam menganalisis peran dari setiap argumen, jika ditinjau dari verba yang digunakan, verba itte yang berasal dari verba iu yang bermakna berkata, memerlukan adanya pihak yang mengatakan sesuatu dan pihak yang mendengarkan perkataan tersebut. Sehingga analisis peran dari masing-masing argumen seperti yang diungkapkan oleh Saeed adalah sebagai berikut.

$\begin{array}{llll}\text { Anata wa } & \text { watashi ni } & \begin{array}{l}\text { sou itte kureru to } \\ \text { berkata demikian }\end{array} & \begin{array}{l}\text { ureshii } \\ \text { berbesar hati }\end{array} \\ \text { Agent } & \text { Baya } & \text { Beneficiary } & \text { Verba-te }\end{array}$

Dari analisis tersebut, dapat diketahui bahwa pihak yang berperan sebagai agent (pihak yang melakukan aksi/tindakan) adalah anata. Sedangkan watashi berperan sebagai beneficiary (pihak yang dikenai/menerima tindakan/kebaikan).

Sedangkan jika ditinjau dari ungkapan jujuhyougen yang digunakan, dapat diketahui bahwa verba kudasaru yang bermakna memberi, memerlukan adanya pihak yang dituju (goal) dan pihak asal yang melakukan aksi/tindakan (source). Dari hal tersebut, analisis mengenai perannya adalah sebagai berikut.

\begin{tabular}{|c|c|c|c|}
\hline$\frac{\text { Anata }}{\text { Kamu }} w a$ & $\frac{\text { watashi }}{\text { saya }}$ & $\begin{array}{l}\text { sou itte kureru to } \\
\text { berkata demikian }\end{array}$ & $\begin{array}{l}\text { ureshii } \\
\text { berbesar hati }\end{array}$ \\
\hline Source & Goal & Verba-iuiu & \\
\hline
\end{tabular}

Dari analisis di atas, dapat diketahui bahwa yang berperan sebagai pihak asal yang melakukan aksi/tindakan (source) adalah anata, dan pihak yang dituju (goal) adalah watashi.

Dalam menganalisis penggunaan ungkapan kureru yang dilakukan oleh Hideyori, hal ini dilatarbelakangi oleh adanya jarak peserta tutur seperti yang diungkapkan oleh Sachiko bahwa 
fungsi jarak dipahami sebagai konsep mendasar untuk mengontrol perilaku manusia dalam kesopanan. Jarak sosial yang ada dalam kalimat tuturan tersebut dilatarbelakangi oleh adanya jarak vertikal yakni kekuasaan yaitu kekuasaan (power). Diketahui bahwa Hideyori adalah seorang kaisar sedangkan Shigenari adalah seorang anak kepala kementerian. Kaisar mempunyai kekuasaan yang lebih dibandingkan anak kepala kementerian. Dari hal tersebut, dapat disimpulkan bahwa status sosial Hideyori lebih tinggi daripada Shigenari. Hal ini sesuai dengan yang diungkapkan oleh Tsujimura bahwa kureru dapat digunakan jika status sosial pemberi lebih rendah dari penerima.

Data 2 merupakan data yang dikutip dari tuturan yang diucapkan oleh Hideyori kepada Yuuraku. Suatu hari Yuuraku mengatakan kepada Hideyori jika terjadi peperangan di kemudian hari, Yuuraku memohon kepada Hideyori untuk memperbolehkannya tidak ikut serta dalam peperangan dengan alasan umurnya yang sudah tua, dan lagi karena sudah lelah setelah sekian lama selalu ikut serta dalam setiap peperangan. Mendengar permohonan Yuuraku tersebut, Hideyori memberikan komentar dengan mengatakan kalimat yang terdapat dalam data tersebut.

Kalimat tersebut adalah struktur kalimat secara lahir yang dituturkan oleh Hideyori kepada Yuuraku (seorang anak buah/bawahan). Perlakuan baik itu dilakukan oleh Yuuraku kepada Hideyori. Dilihat dari struktur kalimat secara batin, dapat ditulis sebagai berikut.

( Senjitsu no tatakai de wa, anata ga watashi ni taisou hataraite kureta soudesune )

(Di peperangan yang terjadi beberapa waktu yang lalu, sepertinya banyak yang telah Anda lakukan untuk saya ya)

Dari kalimat yang bergaris bawah di atas, dapat dianalisis mengenai fungsi dari setiap argumen sebagai berikut.

$\frac{\text { anata ga }}{\text { Anda }} \quad \frac{\text { watashi ni }}{\text { saya }} \quad \begin{gathered}\text { taisou hataraite kureta } \\ \text { banyak melakukan }\end{gathered} \begin{gathered}\text { soudesune } \\ \text { sepertinya }\end{gathered}$


Dari analisis tersebut, dapat diketahui bahwa subjek (S) dalam kalimat tersebut adalah anata. Sedangkan objeknya (O) adalah Yuuraku. Dalam hal ini yang dimaksud sebagai anata adalah Yuuraku dan watashi adalah Hideyori.

Dalam menganalisis peran dari setiap argumen, jika ditinjau dari verba yang digunakan, verba hataraite yang berasal dari verba hataraku yang bermakna melakukan, memerlukan adanya pihak yang melakukan sesuatu dan pihak yang menerima perlakuan tersebut. Sehingga analisis peran dari masing-masing argumen seperti yang diungkapkan oleh Saeed adalah sebagai berikut.

$\begin{array}{llcl}\frac{\text { anata ga }}{\text { Anda }} & \frac{\text { watashi ni }}{\text { saya }} & \frac{\text { taisou hataraite kureta }}{\text { banyak melakukan }} & \begin{array}{c}\text { soudesune } \\ \text { sepertinya }\end{array} \\ \text { Agent } & \text { Beneficiary } & \text { Verba-te } & \end{array}$

Berdasarkan analisis tersebut, dapat diketahui bahwa pihak yang berperan sebagai agent (pihak yang melakukan aksi/tindakan) adalah anata. Sedangkan watashi berperan sebagai beneficiary (pihak yang dikenai/menerima tindakan/kebaikan).

Sedangkan jika ditinjau dari penggunaan ungkapan jujuhyougen yang digunakan, maka analisis perannya adalah sebagai berikut.

\begin{tabular}{|c|c|c|}
\hline$\frac{\text { anata } g a}{\text { Anda }}$ & $\frac{\text { watashi }}{\text { saya }}$ & $\begin{array}{l}\text { taisou_hataraite kureta } \\
\text { banyak melakukan }\end{array}$ \\
\hline Source & Goal & Verba-juju \\
\hline
\end{tabular}

Dari analisis tersebut, dapat diketahui bahwa yang berperan sebagai pihak asal yang melakukan aksi/tindakan (source) adalah anata, dan pihak yang dituju (goal) adalah watashi.

Ditinjau dari penggunaan ungkapan kureru yang digunakan Hideyori, hal ini dilandasi oleh adanya jarak peserta tutur seperti yang diungkapkan oleh Sachiko bahwa fungsi jarak disini dipahami sebagai konsep mendasar untuk mengontrol perilaku manusia dalam kesopanan. Jarak sosial yang ada dalam kalimat tuturan tersebut dilatarbelakangi oleh adanya jarak vertikal yakni kekuasaan (power). Seperti yang telah diketahui bahwa Hideyori yang merupakan seorang kaisar memiliki kekuasaan yang lebih dibandingkan anak buahnya/bawahannya. Dari hal tersebut dapat disimpulkan bahwa Hideyori memiliki status sosial yang lebih tinggi. Sehingga hal ini sesuai dengan yang diungkapkan oleh Tsujimura bahwa kureru dapat digunakan jika status sosial pemberi lebih rendah daripada penerima. Dalam hal ini, penerimanya yaitu Hideyori, dan pemberinya yaitu Yuuraku. 


\section{4. -tekudasaru}

Data yang mengandung ungkapan -tekudasaru di temukan di halaman 77 paragraf 3 yang berbunyi,

1. (Soudeshitaka. Sore wa hontou ni yoikoto wo shitekudasatta) Sungguhkah ini benar-benar hal yang baik memberikan (Sungguh? Ini benar-benar hal baik yang telah anda lakukan pada saya. .....)

Data tersebut merupakan kutipan kalimat yang diucapkan oleh Hideyori kepada Ryoui. Ryoui adalah seorang pedagang besar berumur kira-kira 60 tahun, yang merupakan rekan dari ayahnya dulu. Ryoui bercerita banyak tentang berbagai kehidupan di negeri asing dan bercerita tentang kerjasamanya dengan Taikou dahulu. Ryoui bercerita tentang kerjasamanya dengan Taikou seperti rencana membangun selokan dan kuil di sekitar istana. Namun semua rencana itu tidak terselesaikan dengan baik. Hideyori tidak menyangka hal itu akan terjadi. Kemudian Hideyori mengatakan kalimat yang ada dalam data tersebut kepada Ryoui.

Kalimat tersebut merupakan struktur kalimat secara lahir yang dituturkan oleh Hideyori (seorang kaisar) kepada Ryoui (seorang pedagang). Aktivitas pemberian hal baik tersebut ditujukan kepada Hideyori oleh Ryoui. Sehingga jika dituliskan secara lengkap struktur kalimat batinnya, kalimatnya adalah sebagai berikut.

(Soudeshitaka. Sore wa anata ga watashi ni hontou ni yoikoto wo shitekudasatta)

(Sungguh? Ini benar-benar hal baik yang telah anda lakukan pada saya......)

Dari kalimat yang bergaris bawah di atas, anata yang dimaksud adalah Ryoui. Analisis mengenai fungsi dari setiap argumen dalam kalimat tersebut adalah sebagai berikut.

\begin{tabular}{|c|c|c|c|}
\hline$\frac{\text { anata }}{\text { Anda }} g a$ & $\frac{\text { watashini }}{\text { sava }}$ & hontou ni yoikoto wo & shitekudasatto \\
\hline$S$ & OTL & $\mathrm{OL}$ & $P$ \\
\hline
\end{tabular}

Dari kalimat tersebut, dapat diketahui bahwa subjeknya adalah anata. Objek langsung dalam kalimat tersebut adalah hontouni yoikoto, sedangkan objek tak langsungnya adalah watashi. 
Dalam menganalisis peran dari setiap argumen, jika ditinjau dari verba yang digunakan, verba shite yang berasal dari verba suru yang bermakna melakukan, memerlukan adanya pihak yang melakukan sesuatu dan pihak yang menerima perlakuan tersebut. Sehingga analisis peran dari masing-masing argumen seperti yang diungkapkan oleh Saeed adalah sebagai berikut.

\begin{tabular}{|c|c|c|c|}
\hline$\frac{\text { anata } g a}{\text { Anda }}$ & $\frac{\text { watashi }}{\text { saya }}$ & $\underline{\text { hontou ni yoikoto }} \mathrm{W}$ & o $\frac{\text { shite }}{\text { melakukan }}$ \\
\hline Agent & Beneficiary & Theme & Verba-te \\
\hline
\end{tabular}

Dari analisis tersebut, dapat diketahui bahwa pihak yang berperan sebagai agent (pihak yang melakukan aksi/tindakan) adalah anata, dan yang berperan sebagai beneficiary (pihak yang dikenai/menerima tindakan/kebaikan) adalah watashi, sedangkan sesuatu yang menjadi objek pergerakan tindakannya (theme) adalah hontou ni yoikoto.

Sedangkan jika ditinjau dari ungkapan jujuhyougen yang digunakan, dapat diketahui bahwa verba kudasaru yang bermakna memberi, memerlukan adanya pihak yang dituju (goal) dan pihak asal yang melakukan aksi/tindakan (source). Dari hal tersebut, analisis mengenai perannya adalah sebagai berikut.

\begin{tabular}{|c|c|c|c|c|}
\hline$g a$ & watashini & hontou ni yoikoto wo & וחות & kudasatta \\
\hline & saya & benar-benar hal baik & melakukan & \\
\hline Source & Goal & Theme & & $V \epsilon$ \\
\hline
\end{tabular}

Dari analisis tersebut, dapat diketahui bahwa yang berperan sebagai pihak asal yang melakukan aksi/tindakan (source) adalah anata, dan pihak yang dituju (goal) adalah watashi.

Mengenai analisis penggunaan ungkapan kudasaru, seperti yang telah diuraikan di atas, Hideyori adalah seorang kaisar yang kedudukannya lebih tinggi daripada seorang pedagang. Hal ini menimbulkan pertanyaan mengapa Hideyori yang mempunyai kedudukan lebih tinggi menggunakan ragam bahasa sopan (dalam hal ini penggunaan ungkapan kudasaru) kepada orang yang kedudukannya lebih rendah. Hal ini dilatarbelakangi oleh adanya jarak peserta tutur seperti yang diungkapkan oleh Ide bahwa fungsi jarak dipahami sebagai konsep mendasar untuk mengontrol perilaku manusia dalam kesopanan. Jarak sosial yang ada dalam percakapan ini dilatarbelakangi oleh adanya formalitas peristiwa tersebut. Oleh karena itu, situasi formal 
dalam kalimat ini lebih memegang peranan penting daripada jarak sosial yang ada yakni jarak vertikal. Hideyori yang memiliki status sosial yang lebih tinggi daripada Ryoui, seharusnya dapat menggunakan ragam bahasa biasa, oleh karena adanya keformalitasan situasi tersebut, maka Hideyori menggunakan ragam bahasa sopan.

\section{5. -temorau}

Dalam novel tersebut, ditemukan sebanyak 2 kalimat tuturan yang mengandung temorau, sebagai berikut.

1. Halaman 51 paragraf 5

Sochiwa bukeini hagendeirusoudaga, watashiwa sorewo

Kamu ilmu beladiri katanya sedang berlatih, aku itu

yarasetemoraenai

tidak diizinkan melakukan

(Katanya kamu sedang belajar ilmu beladiri ya, tapi kamu tidak mengizinkanku untuk melakukannya. ....)

2. Halaman 81 paragraf 1

Konokoto wo muneni himete, koushouni atattemoraitai

Hal ini dalam hati memendam, musyawarah ingin dimenangkan

(....Memendam hal ini dalam hati, dan ingin menyelesaikannya dengan jalan musyawarah)

Dalam data 1, kalimat tersebut merupakan kalimat yang dikutip dari tuturan yang diucapkan oleh Hideyori kepada Shigenari. Umur mereka sebaya. Suatu hari, mereka sedang asyik bermain-main. Shigenari sangat pandai dalam memainkan anak panah. Menurut Shigenari, Hideyori tidak pantas untuk melakukannya, oleh karena itu ia tidak mengizinkan Hideyori untuk melakukan hal seperti yang sedang dipelajarinya. Kemudian ia mengatakan kalimat dalam data tersebut.

Kalimat tersebut merupakan struktur kalimat secara lahir yang dituturkan oleh Hideyori (seorang kaisar) kepada Shigenari (anak kepala kementerian). Aktivitas penerimaan izin tersebut dilakukan oleh Hideyori dari Shigenari. Jika dituliskan secara lengkap struktur kalimat batinnya, kalimatnya adalah sebagai berikut.

(Sochiwa bugeini hagendeirusoudaga, watashiwa anata ni sorewo yarasete moraenai )

(Katanya kamu sedang belajar ilmu beladiri ya, tapi kamu tidak mengizinkanku untuk melakukannya) 
Sore yang dimaksud dalam kalimat tersebut adalah bugei (ilmu bela diri), dan anata yang terdapat pada kalimat yang bergaris bawah di atas, adalah Shigenari. Kalimat yang bergaris bawah di atas, jika dianalisis ditinjau dari sisi perannya, maka analisisnya adalah sebagai berikut.

$\begin{array}{cllcc}\text { watashi wa } & \frac{\text { anata ni }}{\text { snda }} & \text { sore wo } & \text { yarasete } & \text { moraenai } \\ \text { saya } & \text { itu } & \text { menyuruh melakukan } & \text { menerima } \\ \text { S } & \text { OTL } & \text { OL } & \text { P } & \end{array}$

Dari analisis tersebut, dapat diketahui bahwa subjeknya (S) adalah watashi, objek langsungnya adalah sore, dan objek tak langsugnya (OTL) adalah anata.

Setelah menganalisis fungsi dari setiap argumen, kemudian dianalisis mengenai perannya. Dalam menganalisis peran dari setiap argumen dalam kalimat tersebut berdasarkan verba yang digunakan, yakni verba yarasete yang berasal dari verba yaraseru yang bermakna menyuruh melakukan. Dari verba tersebut berarti bahwa ada pihak yang melakukan sesuatu dan ada pihak yang menyuruh pihak lain untuk melakukan sesuatu. Sehingga dapat ditarik kesimpulan bahwa pihak yang menyuruh melakukan sesuatu dalam kalimat tersebut adalah Shigenari sedangkan Hideyori adalah orang yang melakukan sesuatu. Analisis peran dalam kalimat tersebut adalah sebagai berikut.

\begin{tabular}{|c|c|c|c|}
\hline$\frac{\text { watashi wa }}{\text { saya }}$ & $\frac{\text { anata }}{\text { Anda }}$ & $\frac{\text { sore wo }}{i t u}$ & $\begin{array}{l}\text { yarasete } \\
\text { menyuruh melakukan }\end{array}$ \\
\hline Bene & Agent & Theme & Verba-te \\
\hline
\end{tabular}

Dari analisis tersebut, dapat diketahui bahwa pihak yang berperan sebagai agent (pihak yang melakukan aksi/tindakan) adalah anata, dan yang berperan sebagai beneficiary (pihak yang dikenai/menerima tindakan/kebaikan) adalah watashi, sedangkan sesuatu yang menjadi objek pergerakan tindakannya (theme) adalah sore.

Sedangkan jika ditinjau dari ungkapan jujuhyougen yang digunakan, dapat diketahui bahwa verba morau yang bermakna menerima, memerlukan adanya pihak yang dituju (goal) 
dan pihak asal yang melakukan aksi/tindakan (source). Dari hal tersebut, analisis mengenai perannya adalah sebagai berikut.

\begin{tabular}{|c|c|c|c|c|}
\hline$\frac{\text { watashi wa }}{\text { saya }}$ & $\frac{\text { anata }}{\text { Anda }}$ & $\frac{\text { sore }}{i t u}$ wo & $\begin{array}{l}\text { yarasete } \\
\text { menyuruh melakukan }\end{array}$ & $\frac{\text { moraenai }}{\text { menerima }}$ \\
\hline Goal & Source & Theme & & Verba-juju \\
\hline
\end{tabular}

Dari analisis tersebut, dapat diketahui bahwa yang berperan sebagai pihak asal yang melakukan aksi/tindakan (source) adalah anata, dan pihak yang dituju (goal) adalah watashi.

Mengenai analisis penggunaan ungkapan morau yang digunakan oleh Hideyori, hal ini dilandasi oleh adanya jarak peserta tutur seperti yang diungkapkan oleh Sachiko bahwa fungsi jarak disini dipahami sebagai konsep mendasar untuk mengontrol perilaku manusia dalam kesopanan. Jarak sosial yang ada dalam kalimat tuturan tersebut dilatarbelakangi oleh adanya jarak vertikal yakni kekuasaan (power). Seperti yang telah diketahui bahwa Hideyori yang merupakan seorang kaisar memiliki kekuasaan yang lebih dibandingkan Shigenari yang hanya anak kepala kementerian. Dari hal tersebut dapat disimpulkan bahwa Hideyori memiliki status sosial yang lebih tinggi daripada Shigenari. Sehingga hal ini sesuai dengan yang diungkapkan oleh Tsujimura bahwa morau dapat digunakan jika pemberi status sosialnya lebih rendah dari penerima. Dalam hal ini, penerimanya yaitu Hideyori, dan pemberinya yaitu Shigenari.

Data 2, atau data kedua dari -temorau merupakan kalimat yang diucapkan oleh Hideyori kepada Katsumoto. Katsumoto merupakan orang kepercayaan Taikou untuk menjaga perdamaian antara pihak Taikou dan pihak Tokugawa.

Katsumoto mengutarakan bahwa tugas dia saat ini merupakan peran yang terpaksa karena tak ada lagi orang yang pantas menduduki peran tersebut. Untuk menanggapi hal tersebut, kemudian Hideyori mengutarakan bahwa sebenarnya ia ingin mengakhiri peperangan itu dengan jalan mengalah. Kemudian ia mengucapkan kalimat dalam data tersebut kepada Katsumoto.

Kalimat tersebut merupakan struktur kalimat secara lahir yang dituturkan oleh Hideyori (seorang kaisar) kepada Katsumoto (orang kepercayaan istana). Aktivitas penerimaan izin 
tersebut dilakukan oleh Shigenari dari Hideyori. Jika dituliskan secara lengkap struktur kalimat batinnya, kalimatnya adalah sebagai berikut.

( Konokoto wo mune ni himete, watashi wa anata ni koushou ni atattemoraitai )

(Memendam hal ini dalam hati, dan ingin menyelesaikannya dengan jalan musyawarah)

Kalimat yang bergaris bawah di atas, jika ditinjau dari sisi perannya, maka analisisnya adalah sebagai berikut.

\begin{tabular}{|c|c|c|c|}
\hline$\frac{\text { watashi wa }}{\text { sava }}$ & $\frac{\text { anata }}{\text { anda }}$ ni & $\frac{\text { koushou ni atatte }}{\text { menang di musyawarah }}$ & $\frac{\text { moraitai }}{\text { ingin menerima }}$ \\
\hline
\end{tabular}

Dari analisis tersebut, dapat diketahui bahwa subjeknya (S) adalah watashi, objek langsungnya adalah anata.

Dalam menganalisis peran dari setiap argumen, jika ditinjau dari verba yang digunakan, verba atatte yang berasal dari verba ataru yang bermakna menang, memerlukan adanya pihak yang mendapatkan kemenangan tersebut. Sehingga analisis peran dari masingmasing argumen seperti yang diungkapkan oleh Saeed adalah sebagai berikut.

\begin{tabular}{|c|c|c|c|}
\hline watashi wa & $\frac{\text { anata }}{\text { anda }}$ & $\frac{\text { koushou ni atatte }}{\text { menang di musyawarah }}$ & $\begin{array}{l}\text { moraitai } \\
\text { ingin menerima }\end{array}$ \\
\hline Benef & Agent & Verba-te & \\
\hline
\end{tabular}

Dari analisis tersebut, dapat diketahui bahwa pihak yang berperan sebagai agent (pihak yang melakukan aksi/tindakan) adalah anata. Sedangkan watashi berperan sebagai beneficiary (pihak yang dikenai/menerima tindakan/kebaikan).

Sedangkan jika ditinjau dari ungkapan jujuhyougen yang digunakan, maka analisis mengenai perannya adalah sebagai berikut.

\begin{tabular}{|c|c|c|c|}
\hline watashi wa & anata ni & koushou ni_atatte & $\frac{\text { moraitai }}{\text { ingin menerima }}$ \\
\hline Goal & Source & & Verba-juju \\
\hline
\end{tabular}

Dari analisis tersebut, dapat diketahui bahwa yang berperan sebagai pihak asal yang melakukan aksi/tindakan (source) adalah anata, dan pihak yang dituju (goal) adalah watashi. 
Ditinjau dari penggunaan ungkapan morau yang digunakan oleh Hideyori, hal ini dilandasi oleh adanya jarak peserta tutur seperti yang diungkapkan oleh Sachiko bahwa fungsi jarak disini dipahami sebagai konsep mendasar untuk mengontrol perilaku manusia dalam kesopanan. Jarak sosial yang ada dalam kalimat tuturan tersebut dilatarbelakangi oleh adanya jarak vertikal yakni kekuasaan (power). Seperti yang telah diketahui bahwa Hideyori yang merupakan seorang kaisar memiliki kekuasaan yang lebih dibandingkan Katsumoto yang hanya seorang pesuruh. Dari hal tersebut dapat disimpulkan bahwa Hideyori memiliki status sosial yang lebih tinggi daripada Katsumoto. Sehingga hal ini sesuai dengan yang diungkapkan oleh Tsujimura bahwa morau dapat digunakan jika pemberi status sosialnya lebih rendah dari penerima. Dalam hal ini, penerimanya yaitu Hideyori, dan pemberinya yaitu Katsumoto.

\section{6. -teitadaku}

Dalam novel tersebut, ditemukan sebanyak 2 kalimat yang mengandung -teitadaku sebagai berikut,

1. Halaman 73 paragraf 9

Sousaseteitadakimasu......

Berbuat demikian.....

(Akan saya lakukan hal tersebut......)

2. Halaman 81 paragraf 6

..... Tohou ni tatakaino ishi nai koto wo shimesutame, gobodousama ni

Pada saya peperangan hal yang tidak ingin menunjukkan Yang Mulia Ibu

Edo ni gosumai ni natteitadakukoto......

ke Edo tinggal

(...untuk mewujudkan cita-cita almarhum Taikousama yang ingin agar tidak terjadi pertumpahan darah lagi, yaitu dengan jalan Yang Mulia Ibu (Yodogimi) tinggal di Edo....)

Data 1, atau data pertama yang mengandung -teitadaku tersebut merupakan kutipan kalimat yang diucapkan oleh Ryoui kepada Hideyori. Ryoui dipanggil untuk menghadap Hideyori. Hideyori ingin mendengar cerita yang lebih banyak tentang dia. Saat menghadap, Hideyori mempersilakannya untuk menikmati sajian yang telah disediakan sesuka hatinya. Kemudian Ryoui menjawab dengan kalimat dalam data tersebut. 
Kalimat tersebut merupakan struktur kalimat secara lahir yang dituturkan oleh Ryoui (seorang pedagang) kepada Hideyori (seorang kaisar). Aktivitas penerimaan izin tersebut diterima oleh Ryoui dari Hideyori. Jika dituliskan secara lengkap struktur kalimat batinnya, kalimatnya adalah sebagai berikut.

( Watashi wa anata ni sousaseteitadakimasu)

(Akan saya lakukan hal tersebut......)

Yang dimaksud dengan anata adalah Hideyori. Dari kalimat tersebut dapat dianalisis tentang fungsi dari masing-masing argumennya sebagai berikut.

\begin{tabular}{|c|c|c|c|c|}
\hline & anata & ni sou & sasete & itadakimasu \\
\hline Saya & ano & seperti & menyuruh melakukan & menerima \\
\hline$S$ & $\mathrm{OL}$ & & $P$ & \\
\hline
\end{tabular}

Dari analisis tersebut, dapat diketahui bahwa subjeknya (S) adalah watashi, objek langsungnya adalah anata.

Setelah menganalisis fungsi dari setiap argumen, kemudian dianalisis mengenai perannya. Dalam menganalisis peran dari setiap argumen dalam kalimat tersebut berdasarkan verba yang digunakan, yakni verba sasete yang berasal dari verba saseru yang bermakna menyuruh melakukan. Dari verba tersebut berarti bahwa ada pihak yang melakukan sesuatu dan ada pihak yang menyuruh pihak lain untuk melakukan sesuatu. Sehingga dapat ditarik kesimpulan bahwa pihak yang menyuruh melakukan sesuatu dalam kalimat tersebut adalah Hideyori sedangkan Ryoui adalah orang yang melakukan sesuatu. Analisis peran dalam kalimat tersebut adalah sebagai berikut.

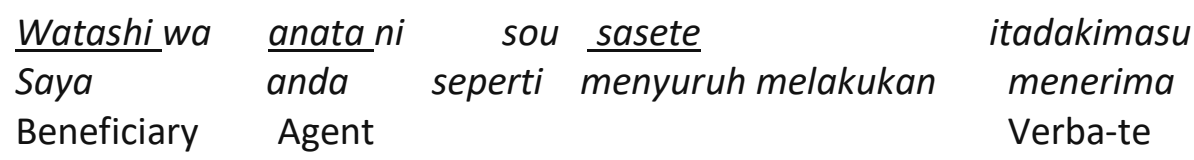

Dari analisis tersebut, dapat diketahui bahwa pihak yang berperan sebagai agent (pihak yang melakukan aksi/tindakan) adalah anata, dan yang berperan sebagai beneficiary (pihak yang dikenai/menerima tindakan/kebaikan) adalah watashi.

Sedangkan jika ditinjau dari ungkapan jujuhyougen yang digunakan, dapat diketahui bahwa verba itadaku yang bermakna menerima, memerlukan adanya pihak yang dituju (goal) 
dan pihak asal yang melakukan aksi/tindakan (source). Dari hal tersebut, analisis mengenai perannya adalah sebagai berikut.

$\begin{array}{llll}\text { Watashi wa } & \text { anatani sou } & \text { sasete } & \text { itadakimasu } \\ \text { Saya } & \text { anda seperti } & \text { menyuruh melakukan } & \text { menerima } \\ \text { Goal } & \text { Source } & & \text { Verba-juju }\end{array}$

Dari analisis tersebut, dapat diketahui bahwa yang berperan sebagai pihak asal yang melakukan aksi/tindakan (source) adalah anata, dan pihak yang dituju (goal) adalah watashi.

Mengenai analisis penggunaan ungkapan itadaku yang digunakan oleh Ryoui, hal ini dilandasi oleh adanya jarak peserta tutur seperti yang diungkapkan oleh Sachiko bahwa fungsi jarak disini dipahami sebagai konsep mendasar untuk mengontrol perilaku manusia dalam kesopanan. Jarak sosial yang ada dalam kalimat tuturan tersebut dilatarbelakangi oleh adanya jarak vertikal yakni kekuasaan (power). Seperti yang telah diketahui bahwa Hideyori yang merupakan seorang kaisar memiliki kekuasaan yang lebih dibandingkan Ryoui yang hanya seorang pedagang. Dari hal tersebut dapat disimpulkan bahwa Hideyori memiliki status sosial yang lebih tinggi daripada Ryoui. Sehingga hal ini sesuai dengan yang diungkapkan oleh Tsujimura bahwa itadaku dapat digunakan jika pemberi status sosialnya lebih tinggi dari penerima. Dalam hal ini, penerimanya yaitu Ryoui, dan pemberinya yaitu Hideyori.

Data 2 dari kalimat yang mengandung -teitadaku tersebut merupakan kalimat yang diambil dari tuturan yang diucapkan oleh Katsumoto kepada Hideyori. Katsumoto memberitahukan bahwa rasa curiga Tokugawa sudah sangat kuat. Untuk menghindari terjadinya pertumpahan darah, hanya ada dua jalan keluar. Kalimat yang diucapkan oleh Katsumoto kepada Hideyori tersebut merupakan salah satu jalan keluar yang ditawarkan oleh Katsumoto kepada Hideyori.

Kalimat tersebut merupakan struktur kalimat secara lahir yang dituturkan oleh Katsumoto (orang kepercayaan istana) kepada Hideyori (seorang kaisar). Aktivitas penerimaan tersebut diterima oleh Katsumoto dari Hideyori. Jika dituliskan secara lengkap struktur kalimat batinnya, kalimatnya adalah sebagai berikut.

( Tohou ni tatakai no ishi nai koto wo shimesutame, watashi wa gobodousama ni Edo ni gosumai ni natteitadakukoto)

(untuk mewujudkan cita-cita almarhum Taikousama yang ingin agar tidak terjadi pertumpahan darah lagi, yaitu Yang Mulia Ibu (Yodogimi) tinggal di Edo) 
Dari kalimat yang bergaris bawah di atas, dapat dianalisis mengenai fungsi dari masingmasing argumen. Analisisnya sebagai berikut.

$\begin{array}{cclc}\text { watashi wa } & \text { gobodousamani } & \text { Edo ni gosumai ni natte } & \text { itadakukoto } \\ \text { Saya } & \text { Yang Mulia Ibu Edo } & \text { tinggal } & \text { menerima } \\ \text { S } & \text { OL } & & \mathrm{P}\end{array}$

Dari analisis tersebut, dapat diketahui bahwa subjeknya (S) adalah watashi, objek langsungnya (OL) adalah gobodousama.

Tahap selanjutnya adalah menganalisis peran dari setiap argumen. Yang pertama ditinjau dari verba yang digunakan. Verba sumai ni natte yang berasal dari verba sumai ni naru berarti bahwa ada pihak yang harus melakukan aktivitas tersebut. Sehingga jika dilihat dari verba yang digunakan maka dapat dianalisis mengenai perannya sebagai berikut.

$\begin{array}{cccc}\text { watashi wa } & \text { gobodousama ni } & \text { Edo ni gosumai ni natte } & \text { itadakukoto } \\ \text { Saya } & \text { Yang Mulia Ibu Edo } & \text { tinggal } & \text { menerima } \\ \text { Beneficiary } & \text { Agent } & & \text { Verba-te }\end{array}$

Dari analisis tersebut, dapat diketahui bahwa pihak yang berperan sebagai agent (pihak yang melakukan aksi/tindakan) adalah gobodousama. Sedangkan watashi berperan sebagai beneficiary (pihak yang dikenai/menerima tindakan/kebaikan).

Dilihat dari ungkapan jujuhyougen yang digunakan yakni itadaku, yang berarti menerima, dapat diketahui bahwa verba tersebut memerlukan adanya pihak yang dituju (goal) dan pihak asal yang melakukan aksi/tindakan (source). Sehingga jika ditinjau dari ungkapan jujuhyougen yang digunakan, maka analisis mengenai perannya adalah sebagai berikut.

$\begin{array}{cccc}\text { watashi wa } & \text { gobodousama ni } & \text { Edo ni gosumai ni natte } & \frac{\text { itadakukoto }}{\text { Saya }} \\ \text { Yang Mulia Ibu Edo } & \text { tinggal } & \text { menerima } \\ \text { Goal } & \text { Source } & & \text { Verba-juju }\end{array}$

Dari analisis tersebut, dapat diketahui bahwa yang berperan sebagai pihak asal yang melakukan aksi/tindakan (source) adalah gobodousama, dan pihak yang dituju (goal) adalah watashi. 
Ditinjau dari penggunaan ungkapan itadaku yang digunakan oleh Katsumoto, hal ini dilandasi oleh adanya jarak peserta tutur seperti yang diungkapkan oleh Ide bahwa fungsi jarak disini dipahami sebagai konsep mendasar untuk mengontrol perilaku manusia dalam kesopanan. Jarak sosial yang ada dalam kalimat tuturan tersebut dilatarbelakangi oleh adanya jarak vertikal yakni kekuasaan (power). Seperti yang telah diketahui bahwa Hideyori yang merupakan seorang kaisar memiliki kekuasaan yang lebih dibandingkan Katsumoto yang hanya seorang bawahan. Dari hal tersebut dapat disimpulkan bahwa Hideyori memiliki status sosial yang lebih tinggi daripada Katsumoto. Sehingga hal ini sesuai dengan yang diungkapkan oleh Tsujimura bahwa itadaku dapat digunakan jika pemberi status sosialnya lebih tinggi dari penerima. Dalam hal ini, penerimanya yaitu Katsumoto, dan pemberinya yaitu Hideyori.

\section{Simpulan}

Berdasarkan hasil analisis data -tejujuhyougen yang telah dilakukan pada novel Jepang berjudul Shiro no Naka no Hito karya Hoshi Shin'ichi, diperoleh hasil bahwa jika ditinjau dari struktur kalimatnya atau secara sintaksis, dalam kalimat yang mengandung -tejujuhyougen, tiap-tiap argumen berfungsi sebagai subjek dan objek.

Jika meninjau peran tiap-tiap argumen dari ancangan semantik, dalam kalimat yang mengandung -tejujuhyougen masing-masing argumen memiliki 2 peran yang dilihat dari kata kerja yang digunakan dan dilihat dari ungkapan jujuhyougen yang digunakan. Jika dilihat dari kata kerja yang digunakan, diketahui siapakah yang menjadi pihak yang melakukan tindakan (agent) dan siapakah yang menjadi pihak yang diuntungkan oleh tindakan yang dilakukan (beneficiary). Sedangkan jika dilihat dari ungkapan jujuhyougen yang digunakan, diketahui siapakah yang menjadi pihak yang dituju (goal) dan siapakah yang menjadi pihak sumber/asal tindakan dilakukan (source).

Jika ditinjau dari secara pragmatik, penggunaan ungkapan jujuhyougen banyak dilatarbelakangi oleh jarak sosial yang dipengaruhi oleh kekuasaan (power). Dengan kata lain, dipengaruhi oleh adanya jarak vertikal. Jarak vertical yang terdapat dalam novel tersebut tampak dari percakapan yang terjadi antara kaisar dan bawahannya. Hamper semua data merupakan kutipan kalimat tuturan dalam percakapan yang terjadi antara Hideyori dengan bawahannya. Meskipun jarak vertikal mempunyai peranan penting dalam pemilihan 
penggunaan ungkapan jujuhyougen yang tepat, namun keformalitasan suatu situasi, memegang peranan yang lebih penting dibandingkan jarak social yang ada. Sehingga hal itu juga mempengaruhi penggunaan ungkapan jujuhyougen yang tepat.

\section{Daftar Pustaka}

Arikunto, Suharsimi. (2002). Prosedur Penelitian Suatu Pendekatan Praktek. Jakarta: Rineka Cipta.

Ken'ichi, Mihara. (1994). Nihongo no Zokugo Kouzou. Toukyou: Shohakusha.

Kurniawati, Safitri Indah. (2008). Pemakaian Ragam Hormat Bahasa Jepang Ditinjau dari Segi Sosiolinguistik dengan Sumber Data Nihongo Jaanaru pada Bab Manga De Manabu Nihongo Kaiwa Jutsu. Skripsi Program Studi Sastra Jepang Fakultas Bahasa dan Sastra Universitas Dian Nuswantoro. Semarang: Universitas Dian Nuswantoro.

Matsuura, Kenji. (1994). Nihongo-Indonesiago Jisho. Kyoto: Kyoto Sangyo University Press. Nakane, Chie. (1970). Masyarakat Jepang. Jakarta: Sinar Harapan.

Retnaningrum, Ana Wuri. (2006). Analisis Kesalahan Mahasiswa Program Studi Bahasa Jepang Universitas Dian Nuswantoro Semarang Dalam Penggunaan Mono No Jujuhyoogen. Proyek Akhir Program Studi D3 Bahasa Jepang Fakultas Bahasa dan Sastra Universitas Dian Nuswantoro Semarang. Semarang: Universitas Dian Nuswantoro.

Rohadi. (2003). Bentuk Ungkapan Kata Kerja Yang Bervariasi. Jakarta: Kesaint Blanc.

Saifudin, Akhmad. (2018). Konteks dalam Studi Linguistik Pragmatik. Lite: Jurnal Bahasa, Sastra, dan Budaya, 14(2), 108-117. http://doi.org/10.5281/zenodo.2631204

Saifudin, Akhmad. (2010). Analisis Pragmatik Variasi Kesantunan Tindak Tutur Terima Kasih Bahasa Jepang dalam Film Beautiful Life Karya Kitagawa Eriko. Lite: Jurnal Bahasa, Sastra, dan Budaya, 6 (2), 172-181.

Saifudin, Akhmad, Bayu Aryanto, Iwan Setiya Budi. (2008). Analisis Fungsi Pragmatik Tindak Tutur Pertanyaan dalam Percakapan Bahasa Jepang antara Wisatawan Jepang dan Pemandu Wisata Indonesia di Candi Borobudur. Lite: Jurnal Bahasa, Sastra, dan Budaya, 4 (1), 8-15.

Saifudin, Akhmad. (2005). Faktor Sosial Budaya dan Kesopanan Orang Jepang dalam Pengungkapan Tindak Tutur Terima Kasih pada Skenario Drama Televisi Beautiful Life Karya Kitagawa Eriko. Tesis Program Studi Kajian Wilayah Jepang Program Pascasarjana Universitas Indonesia Jakarta.

Setiyadi, Ag. Bambang. (2006). Metode Penelitian Untuk Pengajaran Bahasa Asing Pendekatan Kuantitatif dan Kualitatif. Yogyakarta: Graha IImu.

Shin'ichi, Hoshi. (1952). Shiro no Naka no Hito. Tokyo: Kadogawa Shoten.

Sutedi, Dedi. (2004). Dasar-Dasar Linguistik Bahasa Jepang. Bandung: HUP

Takamizawa, Hajime. (2004). Shin Hajimete no Nihongo Kyouiku 1. Japan: ask.

The Japan Fundation. (1990). Nihongo e no Shoutai-Bunpou to Goi. Japan: Bonjinsha.

Tokunaga, Misato. (1992). Dichotomy in The Structures of Honorifics of Japanese, Pragmatics 2: 2, 127-140. 
Tsujimura, Natsuko. (1996). An Introduction To Japanese Linguistics. Jerman: Blackwell.

Wahyuningsih, Putri. (2003). Pemahaman Ungkapan Beri Terima Pada Mahasiswa D3 Bahasa Jepang semester IV dan VI tahun 2002/2003 Universitas Dian Nuswantoro. Proyek Akhir Program Studi D3 Bahasa Jepang Fakultas Bahasa dan Sastra Universitas Dian Nuswantoro. Semarang: Universitas Dian Nuswantoro. 